\title{
Effect of Various Pretreatment Methods on Sugar and Ethanol Production from Cellulosic Water Hyacinth
}

\author{
Shahabaldin Rezania, ${ }^{\mathrm{a} *}$ Hossein Alizadeh, ${ }^{\mathrm{b}}$ Junboum Park, ${ }^{\mathrm{a} *}$ Mohd Fadhil Md Din, ${ }^{\mathrm{c}}$ \\ Negisa Darajeh, ${ }^{\mathrm{d}}$ Shirin Shafiei Ebrahimi, ${ }^{\mathrm{e}}$ Bidyut Baran Saha ${ }^{\mathrm{f}, \mathrm{g}}$ and Hesam Kamyab ${ }^{\mathrm{h}}$ \\ Effects of acid, alkali, ionic liquid (IL), and microwave-alkali pretreatments \\ on cellulosic water hyacinth $(\mathrm{WH})$ were investigated based on the total \\ reducing sugars (TRS) and ethanol production. For the first time, IL \\ pretreatment with (1-Ethyl-3-methylimidazolium acetate ([EMIM][Ac]) was \\ used for $\mathrm{WH}$, and the efficiency was compared with the other methods. \\ Cellulase and Saccharomyces cerevisiae were fermented together for 72 \\ h. Based on the results, all pretreatment methods effectively increased the \\ sugar content as well as the ethanol yield. Untreated WH had $25 \pm 1.5$ \\ $\mathrm{mg} / \mathrm{g}$ of TRS, which was increased to $157 \pm 8.2 \mathrm{mg} / \mathrm{g}, 95 \pm 3.1 \mathrm{mg} / \mathrm{g}, 51 \pm$ \\ $4.2 \mathrm{mg} / \mathrm{g}$, and $45 \pm 2.6 \mathrm{mg} / \mathrm{g}$ via alkali, microwave-alkali, acid, and IL \\ pretreatments, respectively. The highest TRS level of $402 \mathrm{mg} / \mathrm{g}$ was \\ obtained in $24 \mathrm{~h}$ and $6.2 \pm 0.4 \mathrm{~g} / \mathrm{L}$ of ethanol in $48 \mathrm{~h}$ of fermentation with \\ the alkali-treated $\mathrm{WH}$. The ethanol production was followed by other \\ treatment methods of WH in the order of microwave-alkali, acid, and IL. \\ The results indicated that the ethanol production from $\mathrm{WH}$ was related to \\ the type of pretreatment as well as the TRS production.
}

Keywords: Water hyacinth; Ethanol production; Total reducing sugar; Pretreatment methods

Contact information: a: Department of Civil and Environmental Engineering, Seoul National University, Seoul, Republic of Korea; b: Bio-Protection Research Centre, Lincoln University, Lincoln 7647, New Zealand; c: Centre for Environmental Sustainability and Water Security (IPASA), Research Institute for Environmental Sustainability, Universiti Teknologi Malaysia, 81310, Johor Bahru, Malaysia; d: School of Biological Sciences, University of Canterbury, Christchurch 8140, New Zealand; e: School of Education, Universiti Teknologi Malaysia, Johor Bahru, Malaysia; f: International Institute for Carbon-Neutral Energy Research (WPI-I2CNER), Kyushu University, 744 Motooka, Nishi-ku, Fukuoka 819-0395, Japan; g: Mechanical Engineering Department, Kyushu University, 744 Motooka, Nishi-ku, Fukuoka 819-0395, Japan; h: Engineering department, Razak faculty of technology and Informatics, Universiti Teknologi Malaysia, Jalan sultan Yahya Petra, 56100, Kuala Lumpur;

*Corresponding authors: shahab_rezania89@yahoo.com; junbpark@snu.ac.kr

\section{INTRODUCTION}

Fossil fuel depletion in the near future can be predicted by the continuous overutilization of natural energy sources (Jambo et al. 2016). Agricultural products, such as corn, wheat, and sugarcane, are defined as the first generation of raw materials for bioethanol production. Likewise, lignocellulosic biomass is the second generation, and algal biomass is the third generation (Baeyens et al. 2015). This energy source also has the potential to reduce greenhouse gas emissions originating from fossil fuels and by carbon sequestration (Tye et al. 2016). The use of lignocellulosic biomass as the feedstock for fermentable sugar production is the key element in sustaining the production of bioproducts like bioethanol (Mandade et al. 2016). 
Water hyacinth is a type of lignocellulosic material that is potentially available in tropical regions (Sing and Bishnoi 2013; Rezania et al. 2015). In an untreated biomass, cellulose, hemicelluloses, and lignin are linked to form a strong structure that is difficult to process (Rezania et al. 2017). Because the lignin content of the lignocellulose can affect the ethanol production process, the selection of suitable biomass is important. The WH has high carbohydrate and low lignin content, an impressive growth rate, and no competition on land, which makes it a suitable lignocellulosic material for bioenergy generation (Rezania et al. 2016). The economic potential of biofuel production can be improved by using low-lignin biomass in comparison to rich lignin biomass (Bhatt and Shilpa 2014). According to Singh and Bishnoi (2012), there are three main operations needed to convert lignocellulose to bioethanol: pretreatment (necessary to liberate cellulose and hemicellulose), cellulose hydrolysis to produce fermentable sugars, and the fermentation of reducing sugars. In this way, the most common and traditional microorganism used in industrial bioethanol production is the yeast Saccharomyces cerevisiae (Dionisi et al. 2015).

A major challenge for bioethanol production is finding a cost-effective pretreatment of lignocellulosic biomass (Singh et al. 2015). Different cost-effective pretreatment methods have been identified based on different types of lignocellulosic biomass and productivity (Srivastava et al. 2015). The effectiveness of these pretreatments depends on the physical structure and chemical composition of the biomass, as well as the pretreatment conditions (Sarto et al. 2019). The choosing of a pretreatment method can determine the success in overcoming this complicated structure and the factors that constrain the enzymatic hydrolysis of the lignocellulosic biomass (Sun et al. 2016). For instance, to catalyze the polysaccharide in the lignocelluloses, cellulase can serve an important catalytic enzyme with appropriate levels of stability in many ILs (Elgharbawy et al. 2016). In addition, thermal pretreatment, mild alkali pretreatment, and microbial combined dilute acid pretreatment are new approaches for ethanol production from cellulosic WH (Barua and Kalamdhad 2017; Narra et al. 2017; Zhang et al. 2018).

To increase the bioethanol yield, various pretreatment methods are applied to decrease the recalcitrance of lignocellulosic feedstock (Zheng et al. 2014). The supernatant from the lignocelluloses enzymatic hydrolysis contains both hexoses and pentoses sugars (Rezania et al. 2018). As demonstrated by Cheng et al. (2014), the simultaneous processes of pretreatment and wet storage conserve $70 \%$ of carbohydrates and remove $40 \%$ of lignin with $325 \mathrm{mg} / \mathrm{g}$ reduced sugar yield from the WH biomass. Therefore, the aim of this study is to evaluate the effectiveness of acid, alkali, IL, and microwave-alkali pretreatments on the ethanol and total reducing sugars production from WH based on fermentation time. Meanwhile, the main novelty of this study was to use IL pretreatment with 1-ethyl-3methylimidazolium acetate ([EMIM][Ac]) for WH which the efficiency was compared with the mentioned methods.

\section{EXPERIMENTAL}

\section{Materials}

Water hyacinth preparation

The plants were collected from a tank designed for propagation in the environmental lab (IPASA) at the Universiti Teknologi Malaysia, Johor. The WH leaves were separated and washed with distilled water, chopped, oven-dried, and then stored in 
plastic bags for further usage. The chemicals used in this study, such as $\mathrm{NaOH}$ and $\mathrm{H}_{2} \mathrm{SO}_{4}$, were analytical grade reagents. The ionic liquid solution was bought from Sigma Aldrich Company (Kuala Lumpur, Malaysia).

\section{Methods}

Different pretreatment methods

In this study, four types of pretreatment methods were performed using acid, alkali, $\mathrm{IL}$, and microwave-alkali. For the alkali treatment, $10 \mathrm{~g}$ of dried $\mathrm{WH}$ were soaked in an alkali solution for $1 \mathrm{~h}$ followed by a treatment time of $10 \mathrm{~min}$ at $150{ }^{\circ} \mathrm{C}$ inside of a furnace. Then, the hydrolysate was collected via a filtration method (Ahn et al. 2012). For the acid treatment, $10 \mathrm{~g}$ of $\mathrm{WH}$ were mixed with $90 \mathrm{~mL}$ of $4 \%$ dilute sulfuric acid (W/V) and then autoclaved at $120{ }^{\circ} \mathrm{C}$ for $15 \mathrm{~min}$. Then, the treated biomass was neutralized with an addition of calcium hydroxide $(3 \mathrm{~N})$ and filtered using a membrane filter $(0.45 \mu \mathrm{m})$. The solid residues after pretreatment were washed with deionized water, then dried and stored for enzymatic saccharification (Fileto-Pérez et al. 2013).

The IL pretreatment was performed by mixing $51.0 \mathrm{~mL}$ of 1-ethyl-3methylimidazolium acetate ([EMIM][Ac])) with $3 \mathrm{~g}$ of $\mathrm{WH}$ in a 17:1 ratio. The solution was heated and stirred at $120^{\circ} \mathrm{C}$ and incubated for $180 \mathrm{~min}$. To regenerate the $\mathrm{WH}$, equal volumes of deionized water were added to the $\mathrm{WH} /$ solvent solution, which made the precipitation occur quickly. The sample was centrifuged and the supernatant containing IL was removed. Next, the precipitate was washed using deionized water. Finally, the regenerated WH was filtered using Whatman filter paper and oven-dried at $60{ }^{\circ} \mathrm{C}$ for $48 \mathrm{~h}$ in a vacuum (Gao et al. 2013a). The microwave-alkali pretreatment was conducted in a WX-4000 microwave digestion system (Hangzhou, China). In this pretreatment, the WH was treated with $1.0 \%(\mathrm{w} / \mathrm{v}) \mathrm{NaOH}$ solution for $24 \mathrm{~h}$ at $45^{\circ} \mathrm{C}$ in a shaker at $120 \mathrm{rpm}$, then heated for $1.0 \mathrm{~min}$ at $420 \mathrm{w}$ in a microwave oven (SANYO Super Shower Wave 900W, Sanyo Denki America, Inc., Torrance, CA, USA) (Xia et al. 2013). FTIR analysis was performed using (Nicolet iS5, Thermo Fisher Scientific, Inc., USA). The spectra were obtained in the transmission mode and the range of 600 to $4000 \mathrm{~cm}^{-1}$ at a resolution of 4 $\mathrm{cm}^{-1}$ with 32 scans per each sample.

\section{Preparation of yeast as inoculum}

A total of $5 \mathrm{~g}$ of yeast, Saccharomyces cerevisiae (S. cerevisiae) was added to 50 $\mathrm{mL}$ of distilled water and incubated at $37{ }^{\circ} \mathrm{C}$ with $150 \mathrm{rpm}$ for $24 \mathrm{~h}$. The potato dextrose agar medium (PDA) was prepared to culture the yeast cells. Then, $S$. cerevisiae was streaked on the PDA plates to grow the colonies and was kept in an incubator at $37{ }^{\circ} \mathrm{C}$ for $24 \mathrm{~h}$. To enhance the growth rate and activity of $S$. cerevisiae, the best colonies in terms of size were screened and transferred to $50 \mathrm{~mL}$ of nutrient broth (NB) in a $250-\mathrm{mL}$ Erlenmeyer flask at $30{ }^{\circ} \mathrm{C}$.

Later, the plates were transferred to the shaker incubator in $37^{\circ} \mathrm{C}$ for three days. A loopful of the colony was transferred to the test tube and mixed in $50 \mathrm{~mL}$ of distilled water. The tubes were centrifuged in $4000 \mathrm{rpm}$ for $20 \mathrm{~min}$ (the temperature was held at $-4{ }^{\circ} \mathrm{C}$ ). The top layer (supernatant) was discarded and the pellet was collected to measure the optical density (OD) at $600 \mathrm{~nm}$ using a spectrophotometer (HACH DR6000; Loveland, CO, USA). The $S$. cerevisiae suspension cultures were used as an inoculum for fermentation (Mukhopadhyay and Chatterjee 2010). 


\section{Simultaneous saccharification and fermentation (SSF)}

The SSF method was used for the enzymatic hydrolysis and fermentation of the treated WH biomass to produce ethanol. This process consisted of $5 \mathrm{~g}$ of the treated $\mathrm{WH}$ (previously autoclaved for $15 \mathrm{~min}$ at $121{ }^{\circ} \mathrm{C}$ ), filter-sterilized cellulase (extracted from Aspergillus niger) solubilized in $0.1 \mathrm{M}$ sodium phosphate, and $10 \mathrm{~mL}$ of $S$. cerevisiae in a Mendel medium. The initial $\mathrm{pH}$ of the fermentation medium was adjusted to 5.0, and the SSF was carried out at $37^{\circ} \mathrm{C}$ in 250 -mL conical flasks with $80 \mathrm{~mL}$ of fermentation medium and a final volume of $100 \mathrm{~mL}$ with agitation for $72 \mathrm{~h}$. The sampling was completed at 12 $\mathrm{h}$ and approximately $10 \mathrm{~mL}$ of each sample was taken. The samples were centrifuged at $4000 \mathrm{rpm}$ for $15 \mathrm{~min}$ and the pallet was discarded. The supernatant was separated and used to determine the ethanol and reducing sugar content (Eshtiaghi et al. 2012).

\section{Analytical procedures}

The WH composition (cellulose, hemicellulose, and lignin content) was measured according to Di Blasi et al. (1999). The 3,5-dinitrosalicylic acid (DNS) method was used to determine the total sugar reduction in the enzymatic hydrolysate of the acid-treated biomass (Miller 1959). The amount of ethanol during fermentation was measured using gas chromatography (GC) (Model 7890, Hewlet Packard, Waldbronn, Germany) with an FID detector and column HP20 M. The temperatures of the oven, column inlet, and detector were $200{ }^{\circ} \mathrm{C}, 300^{\circ} \mathrm{C}$, and $300{ }^{\circ} \mathrm{C}$, respectively. The carrier gas was helium with a flow rate of $25 \mathrm{~mL} / \mathrm{min}$ (Ang and Abd-Aziz 2015). The ethanol concentration in the samples was identified by comparing the area of the respective sample against the area of a reference sample containing only the standard ethanol. All of the experiments were conducted in triplicate. The theoretical yield value and volumetric ethanol productivity were calculated based on Eqs. 1 to 3:

$$
\begin{aligned}
& \text { Volumetric ethanol productivity }(\mathrm{Qp})=\frac{\text { Ethanol Concentration }}{\text { Fermentation Time }} \\
& \text { Theoretical Yield Value }(\dot{\eta}, \%)=\frac{\text { Ethanol Yield }}{0.51} \times 100 \\
& \text { Ethanol Yield }\left(\frac{\mathrm{g}}{\mathrm{g}}\right)=\frac{\text { Fermentation Medium }(\mathrm{mL})}{\text { Gram Biomass } \times 1000} \times \text { Ethanol Concentration }
\end{aligned}
$$

\section{Theoretical maximum reducing sugar and ethanol yield}

For the calculation of the theoretical maximum reducing sugar yield, it was assumed that the cellulose and hemicellulose in the WH were completely hydrolyzed into hexose (glucose) and pentose (xylose). The weight ratio of the glucose molecule to cellulose was $1.111(180 / 162)$, whereas that of xylose to hemicellulose was 1.136 (150/132). The reaction formula of cellulose conversion transformed into glucose, and the hydrolyze percentage was calculated based on Hu and Wen (2008).

\section{RESULTS AND DISCUSSION}

\section{Composition of Untreated WH}

The untreated WH consisted of $16.4 \pm 0.35 \%$ cellulose, $32.7 \pm 0.14 \%$ hemicellulose, $5.7 \pm 0.05 \%$ lignin, and $10.7 \pm 0.1 \%$ ash content. This demonstrated that WH could be a favorable carbohydrates source. However, Table 1 shows that previous studies obtained different amounts of carbohydrates and lignin from the WH biomass. 
Various geographic conditions, different parts of the WH, different growth states, and methods for drying biomass could be reasons behind these differences.

Table 1. Chemical Composition of Untreated Water Hyacinth

\begin{tabular}{|c|c|c|c|c|c|c|}
\hline $\begin{array}{c}\text { Composition } \\
\text { of WH }\end{array}$ & $\begin{array}{c}\text { (Gao et } \\
\text { al. 2013b) }\end{array}$ & $\begin{array}{c}\text { (Cheng et } \\
\text { al. 2014) }\end{array}$ & $\begin{array}{c}\text { (Zhang et } \\
\text { al. 2015) }\end{array}$ & $\begin{array}{c}\text { (Das et } \\
\text { al. 2016) }\end{array}$ & $\begin{array}{c}\text { (Ruan et al. } \\
2016)\end{array}$ & This Study \\
\hline Cellulose (\%) & 18.3 & 24.15 & 18.07 & 24.7 & 24.5 & $16.4 \pm 0.35$ \\
\hline $\begin{array}{c}\text { Hemicellulose } \\
(\%)\end{array}$ & 23.3 & 27.23 & 28.21 & 32.2 & 34.1 & $32.7 \pm 0.14$ \\
\hline Lignin (\%) & 17.7 & 12.39 & 7.03 & 3.2 & 8.6 & $5.7 \pm 0.05$ \\
\hline
\end{tabular}

Total reducing sugar from different pretreatment methods

Manivannan and Narendhirakannan (2015) observed that the amount of glucose, xylose, and TRS range from $7 \mathrm{mg} / \mathrm{g}$ to $41 \mathrm{mg} / \mathrm{g}$ of WH. To evaluate the effectiveness of different pretreatment methods, the TRS was measured before and after pretreatment, as shown in Table 2.

Table 2. Reducing Sugars by Different Pretreatment Methods

\begin{tabular}{|c|c|c|c|c|c|}
\hline WH Biomass & Untreated & Acid Treated & Alkali Treated & IL Treated & $\begin{array}{c}\text { Microwave- } \\
\text { alkali Treated }\end{array}$ \\
\hline $\begin{array}{c}\text { Total Reducing } \\
\text { Sugars (mg/g of } \\
\text { WH) }\end{array}$ & $25 \pm 1.5$ & $51 \pm 4.2$ & $157 \pm 8.2$ & $45 \pm 2.6$ & $95 \pm 3.1$ \\
\hline
\end{tabular}

The amount of total reducing sugars (hexoses and pentoses) released from the substrate equated to the effectiveness of the pretreatment method (Das et al. 2016). Based on Table 2, the highest rate of TRS obtained was from the alkali pretreatment at $157 \mathrm{mg} / \mathrm{g}$ of WH. This pretreatment enhanced the sugar ratio more than six times more in comparison to the untreated WH (25 mg/g). Similarly, Harun et al. (2011) obtained $24.7 \mathrm{mg}$ sugar/g dry matter of sugars in untreated WH. In a study by Xu et al. (2016), $99 \mathrm{mg} / \mathrm{g}$ yield of TRS from untreated $\mathrm{WH}$ was produced during hydrolysis. The acid, IL, and microwave-alkali pretreatments produced $51 \mathrm{mg} / \mathrm{g}, 45 \mathrm{mg} / \mathrm{g}$, and $95 \mathrm{mg} / \mathrm{g}$ WH of TRS, respectively. In conclusion, the highest TRS was obtained by the alkali-treated $\mathrm{WH}$, followed by microwave-alkali-, acid-, and IL-treated WH, respectively.

\section{TRS production during fermentation}

During fermentation, the majority of reducing sugars were converted to ethanol through the $S$. cerevisiae activity. Initially, the TRS was increased by the cellulase activity, and then decreased due to the sugar consumption by S. cerevisiae to produce ethanol. The high TRS production was due to breakage of the cellulosic structure by the cellulase, which resulted in the exposure of more sugars to microorganisms. In addition, the treated biomass in all pretreatment methods showed an increase in sugar amount in comparison to the untreated biomass. The pretreatments were effective in increasing the TRS during fermentation for ethanol production.

\section{TRS from alkali and microwave-alkali treated WH}

Based on Fig. 1a and Table 2, the highest reducing sugar was obtained from the alkali-treated WH. Initially, $157 \mathrm{mg} / \mathrm{g}$ of reducing sugars were obtained from the alkali- 
treated sample and then were increased up to $402 \mathrm{mg} / \mathrm{g}$ after $24 \mathrm{~h}$ of fermentation. The reduction was observed afterwards due to the sugar consumption by the microorganisms until the end of the experiment. Similarly, Ganguly et al. (2013) observed $465 \mathrm{mg} / \mathrm{g}$ of TRS after an alkali pretreatment of WH. The high level of TRS was due to the availability of large amounts of monosaccharide (cellulose and hemicellulose) after the alkali pretreatment.
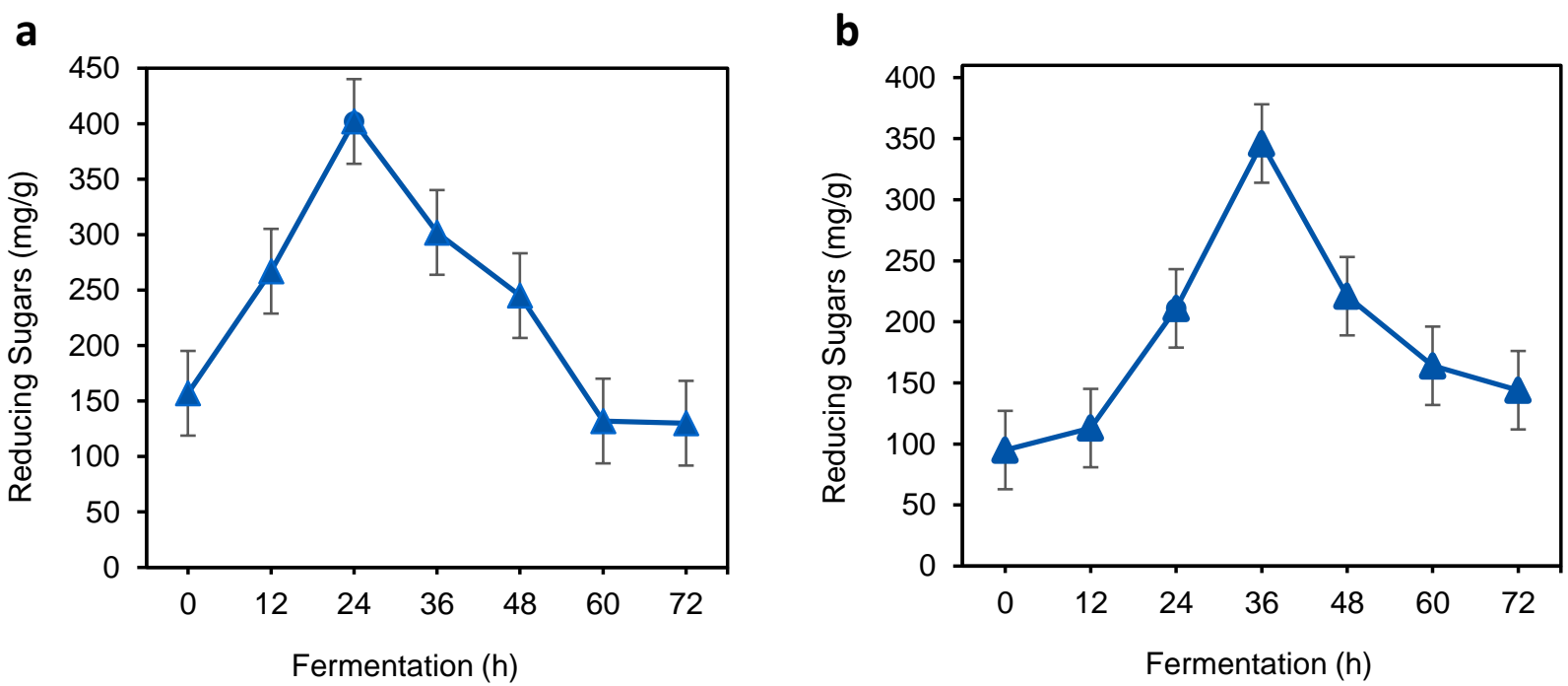

Fig. 1. TRS of alkali-treated and microwave-alkali-treated WH in fermentation: a) alkali-treated and b) microwave-alkali-treated

As shown in Fig.1b, a sharp increment of TRS occurred from $95 \mathrm{mg} / \mathrm{g}$ to $346 \mathrm{mg} / \mathrm{g}$ in $36 \mathrm{~h}$ by the microwave-alkali-treated $\mathrm{WH}$. The radiation successfully enhanced the amount of reducing sugars in the WH biomass. The TRS decreased sharply until the end of the fermentation at $72 \mathrm{~h}$ based on the $S$. cerevisiae activity in the fermentation flask and reached $144 \mathrm{mg} / \mathrm{g}$ at $72 \mathrm{~h}$. Meanwhile, Zhang et al. (2015) obtained only up to $99.12 \mathrm{mg} / \mathrm{g}$ of TRS from the microwave-alkali-treated WH. Aswathy et al. (2010) observed the maximum reducing sugar yield from the hydrolysis of alkali-treated $\mathrm{WH}$, which was 639.4 $\mathrm{mg} / \mathrm{g}$. In a study by Xia et al. (2013), the maximum reducing sugar yield of $483 \mathrm{mg} / \mathrm{g}$ from WH substrate, with $94.6 \%$ of the theoretical reducing sugar yield, was obtained using a microwave-alkali pretreatment. As stated by Singh and Bishnoi (2013), the alkali-treated WH has a higher amount of monosaccharide compared to the acid and oxidative pretreatment. They observed the reducing sugar amount was $5.1 \mathrm{~g} / \mathrm{L}, 6.2 \mathrm{~g} / \mathrm{L}, 9.3 \mathrm{~g} / \mathrm{L}, 13.5$ $\mathrm{g} / \mathrm{L}, 11.3 \mathrm{~g} / \mathrm{L}$, and $8.8 \mathrm{~g} / \mathrm{L}$ after $12 \mathrm{~h}, 24 \mathrm{~h}, 48 \mathrm{~h}, 60 \mathrm{~h}, 72 \mathrm{~h}, 96 \mathrm{~h}$, and $120 \mathrm{~h}$ of fermentation, respectively.

\section{TRS from acid and IL treated water hyacinth}

As shown in Fig. 2a, the highest TRS from acid-treated WH was obtained after 48 $\mathrm{h}$ of fermentation at $236 \mathrm{mg} / \mathrm{g}$ of WH. After $48 \mathrm{~h}$, the TRS was reduced to $62 \mathrm{mg} / \mathrm{g}$ at $72 \mathrm{~h}$ fermentation, which implied sugar consumption by microbes. Zhang et al. (2015) obtained $197.60 \mathrm{mg} / \mathrm{g}$ of TRS in hydrolysates from the acid-treated WH. Meanwhile, $3.79 \mathrm{~g} / \mathrm{L}$ to $5.27 \mathrm{~g} / \mathrm{L}$ of total reducing sugars was obtained from the alkali-treated WH using $S$. cerevisiae during fermentation (Manivannan and Narendhirakannan 2015). 
a

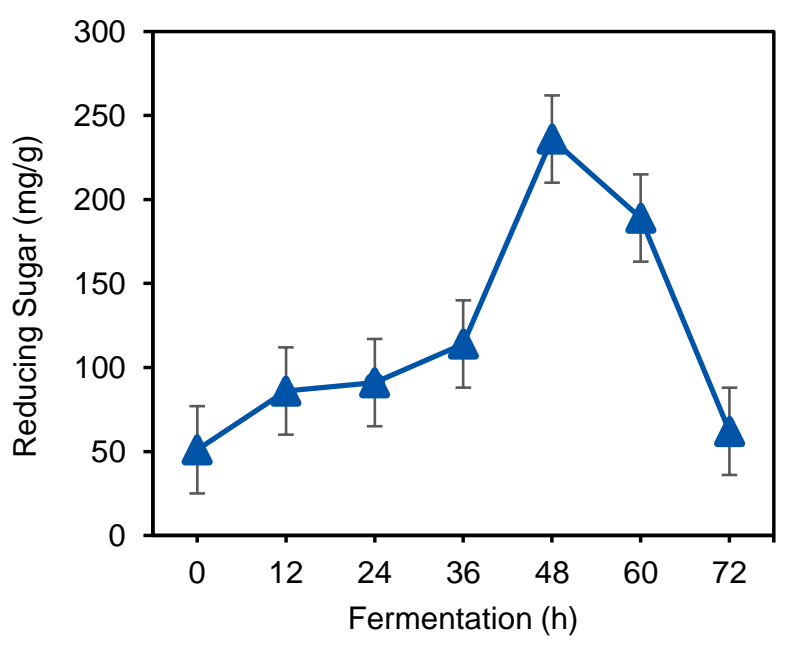

b

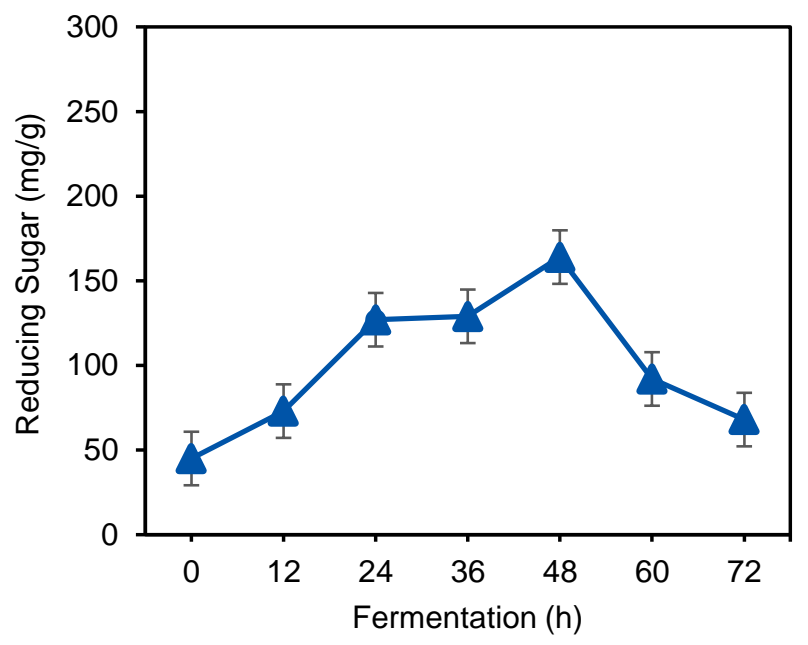

Fig. 2. TRS of acid-treated and IL-treated WH in fermentation: a) acid-treated and b) IL-treated

Similar to other pretreatment methods, the reduction of TRS in the IL-treated sample occurred between $48 \mathrm{~h}$ and $72 \mathrm{~h}$. During this stage, the depletion of sugars occurred in the fermentation due to microorganism activity. The highest TRS was $164 \mathrm{mg} / \mathrm{g}$ at $48 \mathrm{~h}$, and it was reduced to $68 \mathrm{mg} / \mathrm{g}$ at the end of fermentation at $72 \mathrm{~h}$ (Fig. 2b). In this study, only $164 \mathrm{mg} / \mathrm{g}$ of TRS were obtained from the IL-treated WH, which could have been related to the level of lignin in the substrate or type of IL. In contrast, high levels of TRS at $584 \mathrm{mg} / \mathrm{g}$ were obtained from that IL-treated WH 1-butyl-3-methylimidazolium acetate (BMIMA) (Guragain et al. 2011).

\section{FTIR analysis}

For better validation of the effects of various pretreatment methods in the structure of WH, the analysis of FTIR spectra before and after the pretreatment is shown in Fig. 3. After alkali pretreatment of WH, in the range of $1000 \mathrm{~cm}^{-1}$ to $1500 \mathrm{~cm}^{-1}$, five peaks were appeared $1025 \mathrm{~cm}^{-1}, 1154 \mathrm{~cm}^{-1}, 1315 \mathrm{~cm}^{-1}, 1408 \mathrm{~cm}^{-1}$, and $1415 \mathrm{~cm}^{-1}$ (Fig. 3a). These peaks represented the structural features of cellulose and hemicelluloses in WH biomass. Based on the results of this study, the alkali pretreatment increased the amount of cellulose and hemicellulose in WH. In addition, a significant drop of band intensity was observed at $2915^{-1}$, which indicated the reduction in the hydrogen bonding of cellulose in WH structure. In contrast, the absorption band at $2940 \mathrm{~cm}^{-1}$ after alkali pretreatment and enzymatic hydrolysis of WH was observed, as reported by Das et al. (2015)

Based on FTIR spectra of acid treated WH, no peaks in the range of $>1000$ were observed. This means that the acid pretreatment only increased the cellulose of $\mathrm{WH}$ and was not effective in lignin removal (Fig. 3b). Although, Cheng et al. (2014) found the peak intensity of $894 \mathrm{~cm}^{-1}$, which confirms the increase of cellulose after acid treatment of WH due to the removal of amorphous hemicellulose. In addition, because of the complete hydrolysis of hemicellulose, the peak intensity of $1739 \mathrm{~cm}^{-1}$ was remarkably decreased after acid pretreatment. FTIR spectra showed significant reduction of band intensity at $1321 \mathrm{~cm}^{-1}$ (C-H deformation in hemicelluloses) due to the removal of hemicelluloses. 

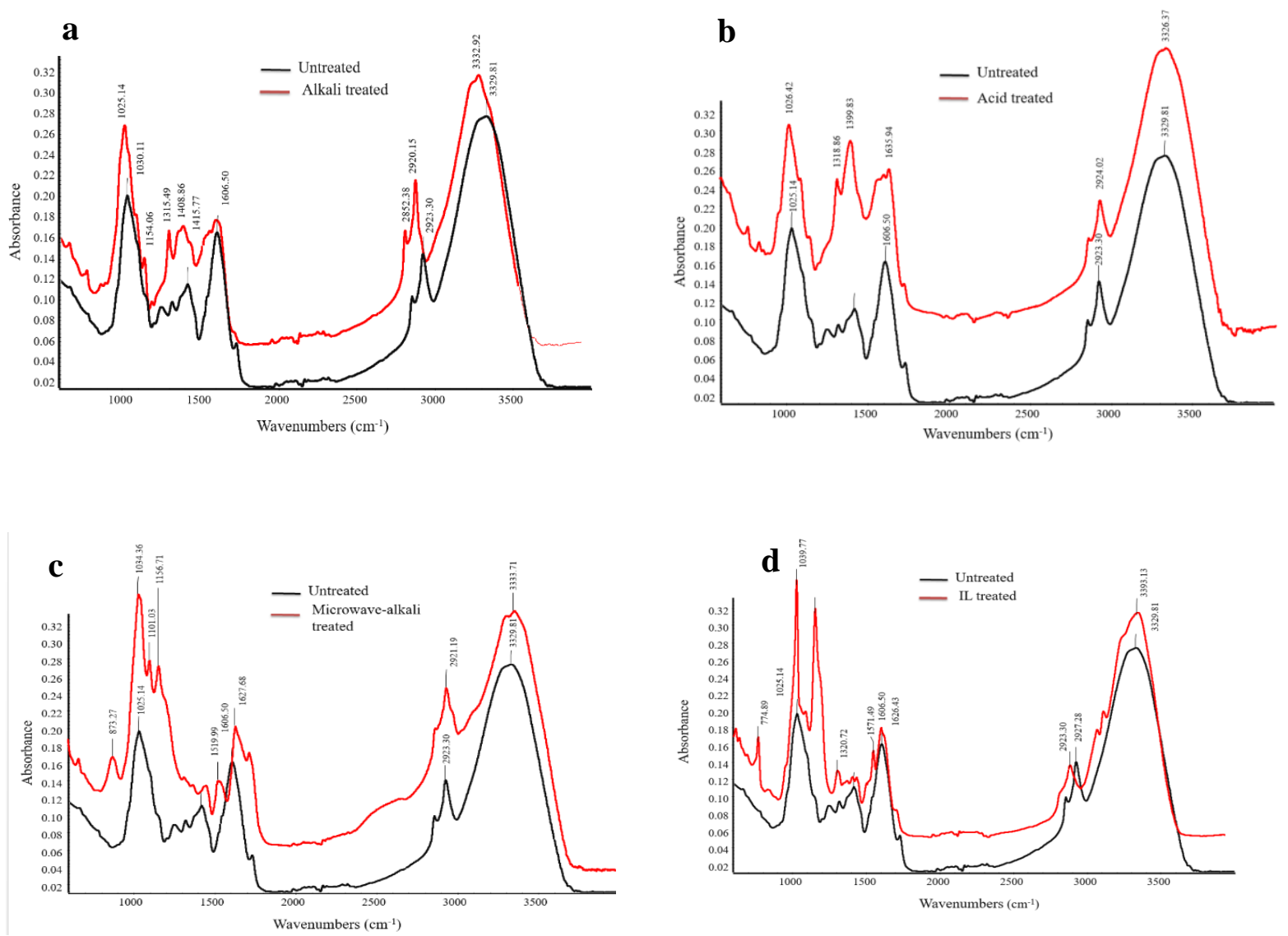

Fig. 3. FTIR analysis of different pretreatments a) Alkali treated WH b) Acid treated WH c) Microwave-alkali treated WH d) IL treated WH

FTIR spectra of microwave-alkali treated WH showed that the disruption of lignin structure (Fig. 3c). Furthermore, the peak intensity of $1630 \mathrm{~cm}^{-1}$ in $\mathrm{C}=\mathrm{O}$ of acetyl groups of lignin dropped due to the lignin cleavage. Furthermore, it also confirmed that the microwave irradiation was effective for complete hydrolysis of tough WH structure (de Souza Moretti et al. 2014).

In FTIR spectra of IL treated WH there was a sharp band at $774 \mathrm{~cm}^{-1}$, which corresponds to the $\mathrm{C} 1$ group frequency and can be attributed to the $\beta$-glycosidic linkages $(1 \rightarrow 4)$ between xylose units in hemicelluloses. Another peak appeared at $1,240 \mathrm{~cm}^{-1}$ corresponding to ( $\mathrm{C}-\mathrm{O}$ stretching in lignin and hemicellulose), which was indicative of the removal of hemicellulose (Fig. 4d).

Similarly, 2922, 1427, and $1373 \mathrm{~cm}^{-1}$ bands were related to the characteristic of cellulose and did not substantially change due to the protection of cellulose during IL pretreatment (Xia et al. 2013). Furthermore, IL pretreatment had more contribution in disruption of $\beta$-glycosidic linkages and hemicelluloses reduction. Recently, Singh et al. (2018) showed that treatment of WH using different imidazolium-based ILs such as [1alkyl-3-methylimidazolium bromide, [Cnmim] $\mathrm{Br}$, resulted in high levels of cellulose disruption. 


\section{Ethanol Production from Differently Treated WH}

Ethanol production from alkali-and microwave-alkali treated WH

Alkali and microwave-alkali pretreatment are two effective methods for ethanol production from WH. Table 3 shows a summary of some studies that used alkali treated WH in different $\mathrm{NaOH}$ concentration by using $S$. cerevisiae.

Table 3. Ethanol production from alkali-treated WH in different studies

\begin{tabular}{|c|c|c|c|c|}
\hline $\begin{array}{c}\mathrm{NaOH} \\
\text { concentration }\end{array}$ & \multicolumn{1}{|c|}{ Yeast type } & $\begin{array}{c}\text { Fermentation } \\
(\mathrm{h})\end{array}$ & $\begin{array}{c}\text { Ethanol yield } \\
(\mathrm{g} / \mathrm{L})\end{array}$ & Reference \\
\hline $1.0 \%$ & $\begin{array}{c}\text { S. cerevisiae } \\
\text { and } \\
\text { Pachysolen } \\
\text { tannophilus }\end{array}$ & 48 & 5.2 & $\begin{array}{c}\text { (Mukhopadhyay } \\
\text { and Chatterjee } \\
\text { 2010) }\end{array}$ \\
\hline $5.0 \%$ & S. cerevisiae & 36 & $4.3 \pm 0.8$ & $\begin{array}{c}\text { (Singh and Bishnoi } \\
\text { 2013) }\end{array}$ \\
\hline $5.0 \%$ & S. cerevisiae & 48 & 3.07 & $\begin{array}{c}\text { (Ganguly et al. } \\
\text { 2013) }\end{array}$ \\
\hline $5.0 \%$ & S. cerevisiae & 72 & 6.76 & (Das et al. 2015) \\
\hline
\end{tabular}

As shown in Fig. 4a and Table 2, the alkali-treated WH had the highest TRS at 402 $\mathrm{mg} / \mathrm{g}$ and the highest ethanol was produced at $48 \mathrm{~h}$ of fermentation by $6.2 \pm 0.4 \mathrm{~g} / \mathrm{L}$.

a

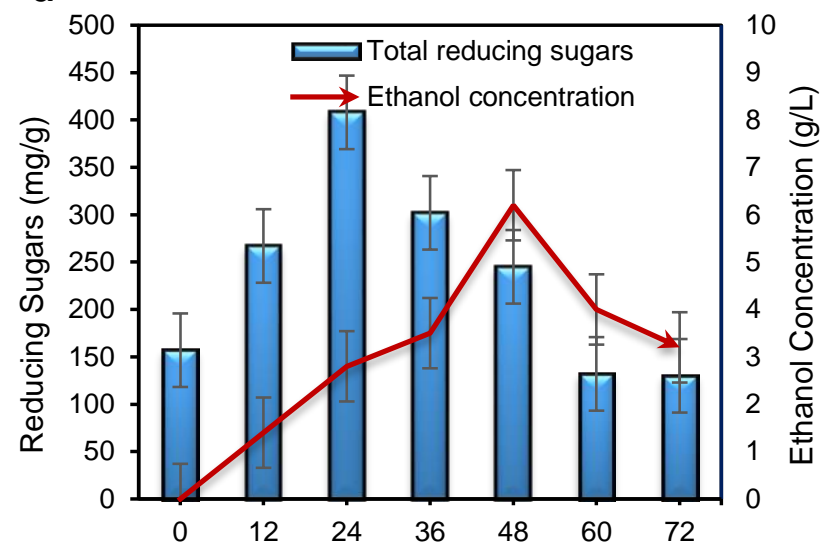

Fermentation (h) b

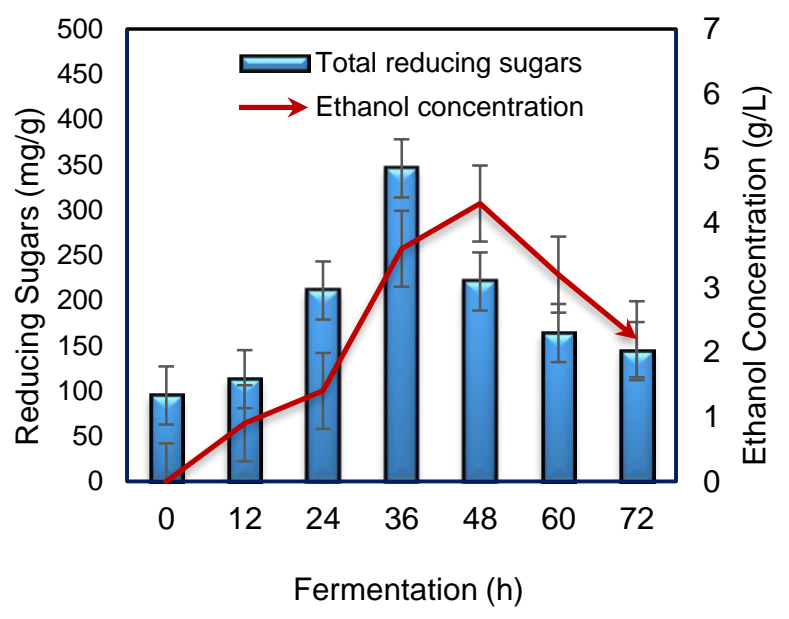

Fig. 4. Ethanol production: a) alkali-treated WH and b) microwave-alkali-treated WH

Das et al. (2015) found that the higher ethanol yield by $P$. stipitis was due to the utilization of both pentose and hexose. Ethanol production based on sugar consumption in the alkali-treated WH is shown in Fig. 4a. The ethanol production from the microwavealkali-treated WH based on TRS is shown in Fig. 4b. By using microwave-alkali-treated $\mathrm{WH}, 4.3 \pm 0.5 \mathrm{~g} / \mathrm{L}$ of ethanol with an ethanol yield of $0.86 \mathrm{~g} / 5 \mathrm{~g}$ of $\mathrm{WH}$ and 0.059 of volumetric ethanol productivity in $48 \mathrm{~h}$ of fermentation was produced. Meanwhile, the highest amount of TRS was $346 \mathrm{mg} / \mathrm{g}$ in $36 \mathrm{~h}$. The ethanol production via microwavealkali increased sharply after $24 \mathrm{~h}$ to $48 \mathrm{~h}$. Therefore, the constant reduction occurred due to the low rate of TRS production during fermentation. 


\section{Ethanol production from acid and IL treated WH}

Figure 5a shows the ethanol production from the acid-treated WH based on TRS and fermentation time. The acid-treated $\mathrm{WH}$ produced $1.8 \pm 0.8 \mathrm{~g} / \mathrm{L}$ of ethanol with a 0.025 productivity and yield of $0.03 \mathrm{~g} / \mathrm{g}$ of $\mathrm{WH}$ in $60 \mathrm{~h}$ of fermentation. In addition, the sugar level was drastically decreased because of the TRS consumption by the microbes for ethanol production. In this study, 4\% (w/v) $\mathrm{H}_{2} \mathrm{SO}_{4}$ was applied and $236 \mathrm{mg} / \mathrm{g}$ of TRS were obtained at $36 \mathrm{~h}$ of fermentation. In previous studies, $33.3 \mathrm{~g} / \mathrm{L}$ of total sugars were obtained in optimized conditions by Reales-Alfaro et al. (2013) and $21 \mathrm{~g} / \mathrm{g}$ by Nigam (2002) after pretreatments with sulfuric acid. These findings further support the idea that the amount of sugars released from the substrate depends on the pretreatment method efficiency and the enzyme activity. As cellulase cleaves the cellobiose units to liberate glucose due to high $\beta$ glucosidases activity about 21.39 (U/gDS), it effectively enhanced the TRS production and subsequently some end products such as ethanol. As reported by Alvira et al. (2010), the presence of ILs residues could have a significant negative effect on cellulase activity. Therefore, to prevent the decrease of final sugars concentrations, ILs removal is necessary.
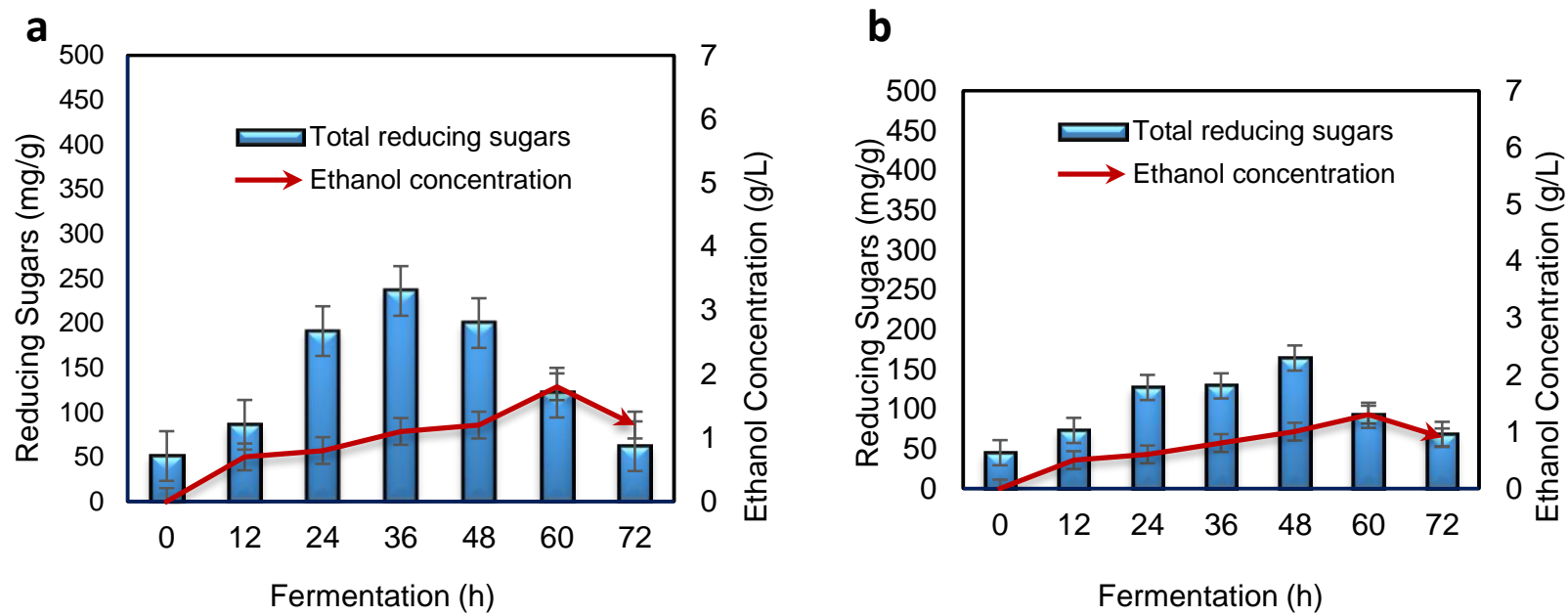

Fig. 5. Ethanol production: a) acid-treated WH and b) IL-treated WH

In this study, the lowest ethanol yield and TRS production were obtained from the IL-treated WH. Hence, there are not many published studies using IL pretreatment for ethanol production from WH. It could hinder the enzymatic hydrolysis as well, as reported by Guragain et al. (2011). The reason could be due to a high moisture content of WH, which leads to a reaction of water molecules with IL solvents during fermentation. Besides, some small molecules such as fructose and lignin can be dissolved in IL solutions during the pretreatment process (Gao et al. 2013a).

Based on Fig. $5 b$, the IL-treated WH produced $1.3 \pm 0.9 \mathrm{~g} / \mathrm{L}$ of ethanol with a volumetric productivity of 0.018 and a yield of $0.02 \mathrm{~g} / 5 \mathrm{~g}$ of $\mathrm{WH}$. The highest ethanol production was obtained at $60 \mathrm{~h}$, and the highest TRS was obtained at $48 \mathrm{~h}$. As demonstrated by Guragain et al. (2011), by using a dilute acid pretreatment on $\mathrm{WH}$, the hydrolysis yields of glucose and total reducing sugars were 2.1 and 3.3 times higher than IL pretreatments. Glucose and total sugars yield of the IL pretreatments were $332 \mathrm{mg} / \mathrm{g}$ and $584 \mathrm{mg} / \mathrm{g}$ of WH, respectively. One of the reasons for such results could have been due to the solubilization of the majority of all hemicelluloses in dilute acid pretreatments. 
Theoretical maximum reducing sugar and ethanol yield

In this study, a maximum theoretical yield of reducing sugar for untreated WH was $(18.2+37.2)=0.554 \mathrm{~g} / \mathrm{g}$ of untreated WH biomass. Theoretically, $0.51 \mathrm{~kg}$ of ethanol per kilogram can be obtained from glucose and xylose. Therefore, the maximum theoretical ethanol yield of WH was $(0.554 \times 0.51)=0.282 \mathrm{~g} / \mathrm{g}$ of raw biomass of WH. However, Das et al. (2015) state the maximum theoretical ethanol yield as $0.3659 \mathrm{~g} / \mathrm{g}$ of WH, which was $0.294 \mathrm{~g} / \mathrm{g}$ of WH as reported by Cheng et al. (2014). This is comparable to ethanol yields of other lignocellulosic materials, such as rice straw with $0.326 \mathrm{~g} / \mathrm{g}$ (Imman et al. 2015). Table 4 shows the ethanol productivity and yield by different types of pretreatment methods. Conditions of fermentation, species, and carbohydrate content of WH notably contributed to ethanol production.

Table 4. Ethanol Production from Differently Treated WH

\begin{tabular}{|c|c|c|c|c|c|}
\hline $\begin{array}{c}\text { Different } \\
\text { Pretreatments }\end{array}$ & $\begin{array}{c}\text { Highest } \\
\text { Level of } \\
\text { TRS }(\mathrm{g} / \mathrm{g})\end{array}$ & $\begin{array}{c}\text { Highest } \\
\text { Ethanol }(\mathrm{h})\end{array}$ & $\begin{array}{c}\text { Ethanol } \\
\text { Production } \\
(\mathrm{gp} / \mathrm{L})\end{array}$ & $\begin{array}{c}\text { Volumetric } \\
\text { Ethanol } \\
\text { Productivity }\end{array}$ & $\begin{array}{c}\text { Yield }(\mathrm{g} \\
\text { Ethanol/5 } \\
\mathrm{g} \mathrm{WH})\end{array}$ \\
\hline Alkali & 402 & 48 & $6.2 \pm 0.4$ & 0.086 & 0.12 \\
\hline Microwave-alkali & 346 & 48 & $4.3 \pm 0.5$ & 0.059 & 0.086 \\
\hline Acid & 234 & 60 & $1.8 \pm 0.8$ & 0.025 & 0.03 \\
\hline Ionic Liquid & 164 & 60 & $1.3 \pm 0.9$ & 0.018 & 0.02 \\
\hline
\end{tabular}

\section{CONCLUSIONS}

1. The IL pretreatment with 1-ethyl-3-methylimidazolium acetate ([EMIM][Ac]) was not effective for sugar and ethanol production from WH.

2. The most effective pretreatment method was alkali followed by microwave-alkali, acid, and IL.

3. FTIR analysis showed a decrease of the band at $1430 \mathrm{~cm}^{-1}$ in all treated samples, which confirmed the effective disruption of the crystalline structure of $\mathrm{WH}$.

4. The highest ethanol yield was $6.2 \pm 0.4 \mathrm{~g} / \mathrm{L}$ via alkali-treated biomass with 0.086 volumetric ethanol productivity and an ethanol yield of $0.012 \mathrm{~g} / 5 \mathrm{~g}$ of WH in $48 \mathrm{~h}$.

5. The acid, microwave-alkali, and IL-treated WH produced $4.3 \pm 0.5 \mathrm{~g} / \mathrm{L}, 1.8 \pm 0.8 \mathrm{~g} / \mathrm{L}$, and $1.3 \pm 0.9 \mathrm{~g} / \mathrm{L}$ of ethanol, respectively.

\section{ACKNOWLEDGMENTS}

This research was supported by a grant (2016R1D1A1A02937267) provided by Korean National Research Foundation (KNRF) which is part of project individual basic science \& engineering research program (SGER). 


\section{REFERENCES CITED}

Ahn, D. J., Kim, S. K., and Yun, H. S. (2012). “Optimization of pretreatment and saccharification for the production of bioethanol from water hyacinth by Saccharomyces cerevisiae," Bioprocess Biosystem Engineering 35(1-2), 35-41. DOI: 10.1007/s00449-011-0600-5

Alvira, P., Tomás-Pejó, E., Ballesteros, M. J., and Negro, M. J. (2010). "Pretreatment technologies for an efficient bioethanol production process based on enzymatic hydrolysis: a review, "Bioresource Technology 101(13), 4851-4861. DOI: 10.1016/j.biortech.2009.11.093

Ang, S. K., and Abd-Aziz, S. (2015). "Potential uses of xylanase-rich lignocellulolytic enzymes cocktail for oil palm trunk (OPT) degradation and lignocellulosic ethanol production," Energy \& Fuels 29(8), 5103-5116. DOI:

10.1021/acs.energyfuels.5b00891

Aswathy, U. S., Sukumaran, R. K., Devi, G. L., Rajasree, K. P., Singhania, R. R., and Pandey, A. (2010). "Bio-ethanol from water hyacinth biomass: An evaluation of enzymatic saccharification strategy," Bioresource Technology 101(3). 925-930. DOI: 10.1016/j.biortech.2009.08.019

Baeyens, J., Kang, Q., Appels, L., Dewil, R., Lv, Y., and Tan, T. (2015). "Challenges and opportunities in improving the production of bio-ethanol," Progress in Energy and Combustion Science 47, 60-88. DOI: 10.1016/j.pecs.2014.10.003

Barua, V. B., and Kalamdhad, A. S. (2017). "Effect of various types of thermal pretreatment techniques on the hydrolysis, compositional analysis and characterization of water hyacinth," Bioresource Technology 227, 147-154. DOI: 10.1016/j.biortech.2016.12.036

Bhatt, S. M., and Shilpa (2014). "Lignocellulosic feedstock conversion, inhibitor detoxification and cellulosic hydrolysis: A review," Biofuels 5(6), 633-649. DOI: 10.1080/17597269.2014.1003702

Cheng, J., Wang, X., Huang, R., Liu, M., Yu, C., and Cen, K. (2014). "Producing ethanol from water hyacinth through simultaneous saccharification and fermentation with acclimatized yeasts," BioResources 9(4), 7666-7680. DOI: 10.15376/biores.9.4.76667680

Das, S. P., Gupta, A., Das, D., and Goyal, A. (2016). "Enhanced bioethanol production from water hyacinth (Eichhornia crassipes) by statistical optimization of fermentation process parameters using Taguchi orthogonal array design," International Biodeterioration \& Biodegradation 109, 174-184. DOI: 10.1016/j.ibiod.2016.01.008

Das, S., Bhattacharya, A., Haldar, S., Ganguly, A., Gu, S., Ting, Y. P., and Chatterjee, P. K. (2015). "Optimization of enzymatic saccharification of water hyacinth biomass for bio-ethanol: Comparison between artificial neural network and response surface methodology," Sustainable Materials and Technologies 3, 17-28. DOI: 10.1016/j.susmat.2015.01.001

de Souza Moretti, M. M., Bocchini-Martins, D. A., Nunes, C. D. C. C., Villena, M. A., Perrone, O. M., da Silva, R., Boscolo, M., and Gomes, E. (2014). "Pretreatment of sugarcane bagasse with microwaves irradiation and its effects on the structure and on enzymatic hydrolysis "Applied Energy 122, 189-195. DOI:

10.1016/j.apenergy.2014.02.020 
Di Blasi, C., Signorelli, G., Di Russo, C., and Rea, G. (1999). "Product distribution from pyrolysis of wood and agricultural residues," Industrial \& Engineering Chemistry Research 38(6), 2216-2224. DOI: 10.1021/ie980711u

Dionisi, D., Anderson, J. A., Aulenta, F., McCue, A., and Paton, G. (2015). “The potential of microbial processes for lignocellulosic biomass conversion to ethanol: A review," Journal of Chemical Technology and Biotechnology 90(3), 366-383. DOI: $10.1002 /$ jctb.4544

Elgharbawy, A. A., Alam, M. Z., Moniruzzaman, M., and Goto, M. (2016). “Ionic liquid pretreatment as emerging approaches for enhanced enzymatic hydrolysis of lignocellulosic biomass," Biochemical Engineering Journal 109, 252-267. DOI: 10.1016/j.bej.2016.01.021

Eshtiaghi, M. N., Yoswathana, N., Kuldiloke, J., and Ebadi, A. G. (2012). "Preliminary study for bioconversion of water hyacinth (Eichhornia crassipes) to bioethanol," African Journal of Biotechnology 11(21), 4921-4928.

Fileto-Pérez, H. A., Rutiaga-Quiñones, J. G., Aguilar-González, C. N., Paéz, J. B., López, J., and Rutiaga-Quiñones, O. M. (2013). "Evaluation of Eichhornia crassipes as an alternative raw material for reducing sugars production," BioResources 8(4), 53405348. DOI: 10.15376/biores.8.4.5340-5348

Ganguly, A., Halder, S., Laha, A., Saha, N., Chatterjee, P. K., and Dey, A. (2013). "Effect of alkali pretreatment on water hyacinth biomass for production of ethanol," Advanced Chemical Engineering Research 2(2), 40-44.

Gao, J., Chen, L., Yan, Z., and Wang, L. (2013a). "Effect of ionic liquid pretreatment on the composition, structure and biogas production of water hyacinth (Eichhornia crassipes)," Bioresource Technology 132, 361-364. DOI: 10.1016/j.biortech.2012.10.136

Gao, J., Chen, L., Yuan, K., Huang, H., and Yan, Z. (2013b). "Ionic liquid pretreatment to enhance the anaerobic digestion of lignocellulosic biomass," Bioresource Technology 150, 352-358. DOI: 10.1016/j.biortech.2013.10.026

Guragain, Y. N., De Coninck, J., Husson, F., Durand, A., and Rakshit, S. K. (2011). "Comparison of some new pretreatment methods for second generation bioethanol production from wheat straw and water hyacinth," Bioresource Technology 102(6), 4416-4424. DOI: 10.1016/j.biortech.2010.11.125

Harun, M. Y., Radiah, A. D., Abidin, Z. Z., and Yunus, R. (2011). "Effect of physical pretreatment on dilute acid hydrolysis of water hyacinth (Eichhornia crassipes)," Bioresource Technology 102(8), 5193-5199. DOI: 10.1016/j.biortech.2011.02.001

$\mathrm{Hu}, \mathrm{Z}$., and Wen, Z. (2008). "Enhancing enzymatic digestibility of switchgrass by microwave-assisted alkali pretreatment," Biochemical Engineering Journal 38(3), 369-378. DOI: 10.1016/j.bej.2007.08.001

Imman, S., Arnthong, J., Burapatana, V., Champreda, V., and Laosiripojana, N. (2015). "Fractionation of rice straw by a single-step solvothermal process: Effects of solvents, acid promoters, and microwave treatment," Renewable Energy 83, 663-673. DOI: 10.1016/j.renene.2015.04.062

Jambo, S. A., Abdulla, R., Azhar, S. H. M., Marbawi, H., Gansau, J. A., and Ravindra, P. (2016). "A review on third generation bioethanol feedstock," Renewable \& Sustainable Energy Reviews 65, 756-769. DOI: 10.1016/j.rser.2016.07.064

Mandade, P., Bakshi, B. R., and Yadav, G. D. (2016). "Ethanol from Indian agroindustrial lignocellulosic biomass: An energy evaluation," Clean Technologies and Environmental Policy 18(8), 2625-2634. DOI: 10.1007/s10098-016-1179-y 
Manivannan, A., and Narendhirakannan, R. T. (2015). Bioethanol production from aquatic weed water hyacinth (Eichhornia crassipes) by yeast fermentation," Waste and Biomass Valorization 6(2), 209-216. DOI: 10.1007/s12649-015-9347-6

Miller, G. L. (1959). "Use of dinitrosalicylic acid reagent for determination of reducing sugar," Analytical Chemistry 31(3), 426-428.

Mukhopadhyay, S. B., and Chatterjee, N. C. (2010). "Bioconversion of water hyacinth hydrolysate into ethanol," BioResources 5(2), 1301-1310. DOI:

10.15376/biores.5.2.1301-1310

Narra, M., Divecha, J., Shah, D., Balasubramanian, V., Vyas, B., Harijan, M., and Macwan, K. (2017). "Cellulase production, simultaneous saccharification and fermentation in a single vessel: A new approach for production of bio-ethanol from mild alkali pre-treated water hyacinth," Journal of Environmental Chemical Engineering 5(3), 2176-2181. DOI: 10.1016/j.jece.2017.04.043

Nigam, J. N. (2002). "Bioconversion of water-hyacinth (Eichhornia crassipes) hemicellulose acid hydrolysate to motor fuel ethanol by xylose-fermenting yeast," Journal of Biotechnology 97(2), 107-116. DOI: 10.1016/S0168-1656(02)00013-5

Reales-Alfaro, J. G., Trujillo-Daza, L. T., Arzuaga-Lindado, G., Castaño-Peláez, H. I., and Polo-Córdoba, Á. D. (2013). "Acid hydrolysis of water hyacinth to obtain fermentable sugars," CT\&F-Ciencia, Tecnología y Futuro 5(2), 101-111.

Rezania, S., Din, M. F. M., Kamaruddin, S. F., Taib, S. M., Singh, L., Yong, E. L., and Dahalan, F. A. (2016). "Evaluation of water hyacinth (Eichhornia crassipes) as a potential raw material source for briquette production," Energy 111, 768-773. DOI: 10.1016/j.energy.2016.06.026

Rezania, S., Din, M. F. M., Mohamad, S. E., Sohaili, J., Taib, S. M., Yusof, M. B. M., and Ahsan, A. (2017). "Review on pretreatment methods and ethanol production from cellulosic water hyacinth," BioResources 12(1), 2108-2124. DOI: 10.15376/biores.12.1.2108-2124

Rezania, S., Din, M. F. M., Taib, S. M., Mohamad, S. E., Dahalan, F. A., Kamyab, H., and Ebrahimi, S. S. (2018). "Ethanol production from water hyacinth (Eichhornia crassipes) using various types of enhancers based on the consumable sugars," Waste and Biomass Valorization 9(6), 939-946. DOI: 10.1007/s12649-017-9883-3

Rezania, S., Ponraj, M., Din, M. F. M., Songip, A. R., Sairan, F. M., and Chelliapan, S. (2015). "The diverse applications of water hyacinth with main focus on sustainable energy and production for new era: An overview," Renewable \& Sustainable Energy Reviews 41, 943-954. DOI: 10.1016/j.rser.2014.09.006

Ruan, T., Zeng, R., Yin, X. Y., Zhang, S. X., and Yang, Z. H. (2016). "Water hyacinth (Eichhornia crassipes) biomass as a biofuel feedstock by enzymatic hydrolysis," BioResources 11(1), 2372-2380. DOI: 10.15376/biores.11.1.2372-2380

Sarto, S., Hildayati, R., and Syaichurrozi, I. (2019). "Effect of chemical pretreatment using sulfuric acid on biogas production from water hyacinth and kinetics," Renewable Energy 132, 335-350. DOI: 10.1016/j.renene.2018.07.121

Singh, A., and Bishnoi, N. R. (2012). "Optimization of ethanol production from microwave alkali pretreated rice straw using statistical experimental designs by Saccharomyces cerevisiae," Industrial Crops and Products 37(1), 334-341. DOI: 10.1016/j.indcrop.2011.12.033

Singh, A., and Bishnoi, N. R. (2013). "Comparative study of various pretreatment techniques for ethanol production from water hyacinth," Industrial Crops and Products 44, 283-289. DOI: 10.1016/j.indcrop.2012.11.026 
Singh, J., Suhag, M., and Dhaka, A. (2015). "Augmented digestion of lignocellulose by steam explosion, acid and alkaline pretreatment methods: A review," Carbohydrate Polymers 117, 624-631. DOI: 10.1016/j.carbpol.2014.10.012

Singh, J., Sharma, R., Ghosh, P., Kumar, A., and Khan, M. L. (2018). “Imidazolium based ionic liquids: A promising green solvent for water hyacinth biomass deconstruction," Frontiers in Chemistry 6, 548. DOI: 10.3389/fchem.2018.00548

Srivastava, N., Rawat, R., Singh Oberoi, H., and Ramteke, P. W. (2015). "A review on fuel ethanol production from lignocellulosic biomass," International Journal of Green Energy 12(9), 949-960. DOI:

Sun, S., Sun, S., Cao, X., and Sun, R. (2016). "The role of pretreatment in improving the enzymatic hydrolysis of lignocellulosic materials," Bioresource Technology 199, 4958. DOI: 10.1016/j.biortech.2015.08.061

Tye, Y. Y., Lee, K. T., Abdullah, W. N. W., and Leh, C. P. (2016). "The world availability of non-wood lignocellulosic biomass for the production of cellulosic ethanol and potential pretreatments for the enhancement of enzymatic saccharification," Renewable \& Sustainable Energy Reviews 60, 155-172. DOI: 10.1016/j.rser.2016.01.072

Xia, A., Cheng, J., Song, W., Yu, C., Zhou, J., and Cen, K. (2013). 'Enhancing enzymatic saccharification of water hyacinth through microwave heating with dilute acid pretreatment for biomass energy utilization," Energy 61, 158-166. DOI: 10.1016/j.energy.2013.09.019

$\mathrm{Xu}, \mathrm{F}$., Chen, L., Wang, A., and Yan, Z. (2016). "Influence of surfactant-free ionic liquid microemulsions pretreatment on the composition, structure and enzymatic hydrolysis of water hyacinth," Bioresource Technology 208, 19-23. DOI: 10.1016/j.biortech.2016.02.027

Zhang, Q., Wei, Y., Han, H., and Weng, C. (2018). "Enhancing bioethanol production from water hyacinth by new combined pretreatment methods, "Bioresource Technology 251, 358-363. DOI: 10.1016/j.biortech.2017.12.085

Zhang, Q., Weng, C., Huang, H., Achal, V., and Wang, D. (2015). “Optimization of bioethanol production using whole plant of water hyacinth as substrate in simultaneous saccharification and fermentation process," Frontiers in Microbiology 6, 1411-1419. DOI: 10.3389/fmicb.2015.01411

Zheng, Y., Zhao, J., Xu, F., and Li, Y. (2014). "Pretreatment of lignocellulosic biomass for enhanced biogas production," Progress in Energy and Combustion Science 42, 35-53. DOI: 10.1016/j.pecs.2014.01.001

Article submitted: August 9, 2018; Peer review completed: November 18, 2018; Revised version received and accepted: November 23, 2018; Published: November 30, 2018. DOI: 10.15376/biores.14.1.592-606 